\title{
The role of vermicompost and chitosan nanoparticles as foliar application to enhancing growth, yield and oil of black cumin (Nigella sativa L.) plants
}

\author{
Ibrahim M. F."
}

Horticulture Department, Faculty of Agriculture, Al-Azhar University, Assiut, Egypt

\begin{abstract}
A field experiment was carried out in Faculty of Agriculture Farm, Al-Azhar University, Assiut, Egypt during two successive seasons 2018/2019 and 2019/2020 aiming to study the effect of four rates of vermicompost (zero, 2, 4 and 6 tons /feddan) (feddan $=4200 \mathrm{~m}^{2}=0.420$ hectares $=1.037$ acres) and three concentrations of chitosan nanoparticles (ChNP) at zero, 20 and 40ppm, as well as, their interaction on growth, yield and chemical constituents of black cumin (Nigella sativa L.) plants. The obtained results showed that all vermicompost levels increased plant height, branch number, herb fresh and dry weights, capsule number and weight/plant, seed weight/plant, 1000 seed weight, fixed and volatile oil percentages and yields and NPK percentages in herb. However, the high rate of vermicompost (6 tons /feddan) gave the best results for these characteristics. Also, treat plants with all concentrations of chitosan nanoparticles (ChNP) showed significant increases in all parameters, except $20 \mathrm{ppm}$ in the second season, regarding branches number comparing to control. The best results were obtained by $40 \mathrm{ppm}$ ChNP in comparison with control. The combined treatment of vermicompost ( 6 tons /feddan) with $40 \mathrm{ppm}$ ChNP recorded the best results of most parameters.
\end{abstract}

Keywords: Nigella sativa, vermicompost, chitosan nanoparticles, oil production.

*Corresponding author: Ibrahim M. F., 


\section{Introduction}

Black cumin (Nigella sativa, L.) is an annual plant belongs to family Ranunculaceae, grows at $20-90 \mathrm{~cm}$ tall, leaves are finely divided, the flowers are white or pale purple color, with 5-10 petals. The fruit is a bloated capsule consists of 3-7 united follicles, each one contains several seeds small in size, odor slightly aromatic and taste bitter (Goreja, 2003). It is a herbaceous plant, one of the most promising medicinal and aromatic plants. This plant is vastly cultivated in the middle and Upper Egypt regions, for seed and oil production. The seeds contain $30-35 \%$ of fixed oil, which has several uses in pharmaceutical and food industries (Ustun et al., 1990). Also, the seeds containing volatile oils $(0.8-1.1 \%$, which mainly contain on nigellon compound), glycosides, saponines, albuminous proteins, tannins, glucose and mucilage resins (Burits and Bucar, 2000). Nigella sativa seeds are used in treatment a lot of diseases, including diabetes, inflammatory diseases, rheumatism, antihypertensive, as well as, improved kidney function and liver in cases of old age and increases the activity of immune cells (Bashandy, 1996; Houghton et al., 1995; Salomi and Rajgopalar, 1989). In the last years, consumers are increasingly concerned about issues such as food quality, environmental safety and soil conservation have led to a substantial increase in the use of sustainable agricultural practices (Tilman et al., 2002). Pollution is increasing day by day, as a result of an accumulation of organic waste and on the other side there is a huge shortage of organic manure. The organic manure could increase the fertility and productivity of the land and produce nutritive and safe food (Ramesh et al., 2005). Recycling organic waste of different resources in the form of compost can be an alternative to meet the increasing demands for organic manures, this will also help to reduce environmental pollution arising out of accumulated organic wastes (Kumar, 2005). Vermicompost is one of the most important fertilizers, which depended on recycling organic waste, where he is a low- tech operation, environmentally friendly process, so vermicompost proved to have many positive effects on plant growth and health (Cristina and Jorge, 2011). Vermicompost is bio-organic manure obtained by passing semidecomposed organic matter through the digestive system by various species of earthworms like Eisenia foetida, Eudrilus $s p$. and its disposal from their body when the materials pass through the worm body, inseminated with intestinal mucosa, vitamins and enzymes. The result is an enriched organic fertilizer which has major applications in agricultural lands, nursery and greenhouses. Recently, there has been much interest in the potential of vermicompost, which are products of a mesophilic, aerobic biodegradation and stabilization of organic matters, produced through interactions between earthworms and microorganisms, as plant growth media and soil amendments (Arancon et al., 2008). Nanotechnology is multispecialty in research field. In this time, a lot of efforts have been made possibility to improve agricultural crops through exhaustive research in nanotechnology (Duhan et al., 2017). Nanotechnology 
includes nanoparticles having one or more dimensions in the order of $100 \mathrm{~nm}$ or less (Auffan et al., 2009). Nanoparticles have found applications in plant protection, nutrition and management of farm practices due to small size and high surface to volume ratio. Chitosan is one of the most important natural polymers. It is polysaccharides called 2-Amino-2deoxybeta-D-glucosasmine, consist of $\mathrm{N}$ acetyl-D-glucosamine (acetylated unit) and $\quad \beta$-(1-4)-linked $\quad \mathrm{D}$-glucosamine (Peniston and Johnson, 1980). Chitosan is derived from chitin, which is considered the external component of marine crustaceans like, shrimp, crabs, shellfish, as well as, cell wall of fungi (Wojdyla, 2001). Chitin can be easily converted to chitosan through extracting the acetyl group and turn it into amino (Sugiyama et al., 2001). Chitosan and its derivatives are nontoxic, biodegradable and friendly to environment. It has been recognized as a product to improve crop production due to their bioactivities to plants, which included stimulating growth of plants and seed germination (Chandrkrachang, 2002). Chitosan nanoparticles (ChNP) has the same characteristics of chitosan and the properties of nanoparticles like, surface and interface effect, small size and quantum size effects (Ingle et al., 2008). The main aim of the present work is to determine the impact of vermicompost fertilizer and chitosan nanoparticles, as well as, their interaction on growth, yield and active ingredients of black cumin plant.

\section{Materials and Methods}

This investigation was carried out at the
Experimental Farm, Faculty of Agriculture, Al-Azhar University, Assiut, Egypt during 2018/2019 and 2019/2020 seasons to study the influence of the addition of vermicompost and chitosan nanoparticles, as well as, their interactions on vegetative growth, yield components, fixed and volatile oil productivity and some chemical constituents of black cumin (Nigella sativa L.) plants. The seeds of black cumin were sown in November $10^{\text {th }}$ of both seasons. The experimental design was a split plot design with three replicates. Vermicompost fertilizer levels were considered as main plots (A), while chitosan nanoparticles concentrations were arranged in the sub plots (B). The experimental unit was $2.0 \times 2.4 \mathrm{~m}$ with $60 \mathrm{~cm}$ distance between the rows, in hills $25 \mathrm{~cm}$ apart on one side of the ridge, each plot contained 3 rows and 21 hills. The plants were thinned after 30 days from planting to one plant/hill to be the number of plants in experimental plot 21 plant. Some physical and chemical properties of the experimental soil (average of the two seasons) are shown in Table (1). The main plots (A) included 4 levels of vermicompost fertilizer, while sub plots contained of foliar spray by three concentrations of chitosan nanoparticles (ChNP). Vermicompost levels were as follows:

- Control treatment.

- 2 tons vermicompost /feddan (feddan $=4200 \mathrm{~m}^{2}=0.420$ hectares $=$ 1.037 acres).

- 4 tons vermicompost/ feddan. 
- 6 tons vermicompost/ feddan.

The concentrations of chitosan nanoparticles treatments were as follows:

- Control (Tap water).

- Chitosan nanoparticles (ChNP) at 20 ppm.

- Chitosan nanoparticles (ChNP) at 40 ppm.
Vermiompost fertilizer was obtained from Central Laboratory for Agricultural Climate (CLAC), Agriculture Research Center, Ministry of Agriculture, Giza, Egypt. Vermicompost was added during the preparation of soil in both seasons. Chitosan nanoparticles was obtained from Naqaa Foundation for Scientific Research, technology and development.

Table (1): Physical and chemical properties of the used soil.

\begin{tabular}{|c|c|c|c|c|c|c|c|c|c|c|c|c|}
\hline Texture & $\begin{array}{c}\text { PH } \\
(1: 2.5)\end{array}$ & $\begin{array}{c}\text { E.C. } \\
(\mathrm{m} . \mathrm{mo} \mathrm{hs} / \mathrm{cm})\end{array}$ & $\begin{array}{c}\mathrm{CaCo} 3 \\
(\%)\end{array}$ & $\begin{array}{c}\text { O.M. } \\
(\%)\end{array}$ & $\begin{array}{c}\text { Total N } \\
(\%)\end{array}$ & \multicolumn{3}{|c|}{ Available } & \multicolumn{3}{|c|}{ Water soluble ions (Meq/l) in the soil } \\
paste
\end{tabular}

${ }^{\mathrm{a}}=\mathrm{SE}$ : standard error. ${ }^{\mathrm{b}}=\mathrm{RR}_{50}$ : resistance ratio $=\mathrm{LC}_{50}$ of the selected generation /

$\mathrm{LC}_{50}$ of the Susceptible strain. ${ }^{\mathrm{c}}=\mathrm{P}$ : Parent field strain.

\subsection{Chitosan nanoparticles preparation method}

One gram chitosan was dissolved in 250 $\mathrm{ml}$ distilled water contains $1 \%$ acetic acid for 20 mints, then $50 \mathrm{ml}$ TPP Sodium Tri polyphosphate solution was dropped into the chitosan beaker at room temperature, after that chitosan solution was magnetically stirred for 45 mints in order to obtain chitosan nanoparticles. The prepared chitosan nanoparticles solution at a concentration of $1 \mathrm{mg} / \mathrm{ml} \quad(1000$ ppm), finally, chitosan nanoparticles stored in distilled water at $2-8{ }^{\circ} \mathrm{C}$, where it will be stable at the prepared size 50 $\mathrm{nm}$ for two months. These concentrations of chitosan nanoparticles were applied as foliar spray twice at one-month intervals, the first was after 45 days from planting, the second was a month later in both seasons. All other agricultural practices were performed as usual. Chemical analysis of vermicompost manure used in this work are shown in Table (2).

Table (2): Chemical analysis of vermicompost manure used in this work.

\begin{tabular}{|l|c|}
\hline Properties & Vermicompost \\
\hline $\mathrm{pH}_{(1: 2.5)}$ suspension & 8.1 \\
\hline $\mathrm{EC}_{(1: 5)}\left(\mathrm{dS} \mathrm{m}^{-1}\right)$ & 6.8 \\
\hline Organic matter \% & 43.3 \\
\hline Total N \% & 1.7 \\
\hline Total $\%$ & 1.15 \\
\hline Total K \% & 0.61 \\
\hline Fe ppm & 1654 \\
\hline Zn ppm & 102 \\
\hline Mn ppm & 98 \\
\hline
\end{tabular}

\subsection{Measured parameters}

\subsubsection{Vegetative growth characteristics}

The plants were randomly selected from each experimental plot at 150 days after planting date and transferred to 
laboratory to record the following data: (plant height $(\mathrm{cm})$, branch number/plant, herb fresh weight $\mathrm{g} /$ plant and herb dry weight $\mathrm{g}$ /plant).

\subsubsection{Yield component characters}

Capsule number /plant, capsule weight/plant, weight of seeds /plant and 1000 seed weight.

\subsubsection{Oil production}

\subsubsection{Fixed oil determination}

The fixed oil \% of the seeds was evaluated by soxhlet apparatus according to A.O.A.C. (1970), then fixed oil yield ( $\mathrm{ml} /$ plant) was calculated by multiplying fixed oil \% in seed weight (g/plant).

\subsubsection{Volatile oil determination}

The volatile oil of seeds was isolated by hydro distillation for 3 hours by Clevenger apparatus according to Guenther (1961), then volatile oil yield (ml /plant) was calculated by multiplying volatile oil \% in seed weight (g/plant).

\subsubsection{Chemical constituents}

\subsubsection{Nitrogen, phosphorus and potassium percentages}

The three studied elements of N, P and $\mathrm{K}$ $\%$ in the dry herb were estimated as follows:

- Nitrogen percentage was determined according to the modified microkjeldahel method as described by Wildy et al. (1985).

- Phosphorus \% was estimated calorimetrically by the spectrophotometer according to Chapman and Pratt (1975).

- Potassium \% was determined by using the Flame-photometer method according to Cottenie et al. (1982).

The Analysis of Variance (ANOVA) and L.S.D multiple range tests at $0.05 \%$ level of probability were used to test the significance of differences between the treatments. Statistical data analyses were performed using Costat software (Steel and Torrie, 1986).

\section{Results and Discussion}

\subsection{Vegetative growth parameters}

The presented data in Table (3) indicated that plant height, branch number, herb fresh weight (g/plant) and herb dry weight (g /plant) of black cumin was significantly augmented, in the two seasons, due to utilizing all levels of vermicompost, except for the low rate of vermicopost 2 tons /feddan in the first season, concerning to plant height as compared to untreated plants. It is clear that the highest value of such traits was obtained due to adding the high level of vermicompost, which increased plant height, branch number, herb fresh weight (g /plant) and herb dry weight (g/plant) 
by 9.4 and $10.5,19.6$ and $22.4,67.0$ and the two experimental seasons, 58.1 and 66.8 and $60.5 \%$ over control in respectively.

Table (3): Influence of vermicompost and chitosan nanoparticles on vegetative growth parameters of black cumin (Nigella sativa L) plants during the seasons of 2018-2019 and 2019-2020.

\begin{tabular}{|c|c|c|c|c|c|c|c|c|}
\hline \multirow{4}{*}{$\begin{array}{l}\text { Vermicompost } \\
\text { Levels (A) }\end{array}$} & \multicolumn{8}{|c|}{ Chitosan nanoparticles concentrations (B) } \\
\hline & \multicolumn{8}{|c|}{ Plant height } \\
\hline & \multicolumn{4}{|c|}{ First season } & \multicolumn{4}{|c|}{ Second season } \\
\hline & Control & $20 \mathrm{ppm}$ & $40 \mathrm{ppm}$ & Mean $(\mathrm{A})$ & Control & $20 \mathrm{ppm}$ & $40 \mathrm{ppm}$ & Mean (A) \\
\hline Control & 55.9 & 64.8 & 67.9 & 62.9 & 58.4 & 67.9 & 68.7 & 65.0 \\
\hline 2 tons /feddan & 58.8 & 67.0 & 69.6 & 65.1 & 62.4 & 68.2 & 71.6 & 67.4 \\
\hline 4 tons /feddan & 61.4 & 67.2 & 70.3 & 66.3 & 64.2 & 68.7 & 72.5 & 68.5 \\
\hline 6 tons /feddan & 63.7 & 69.7 & 72.9 & 68.8 & 65.9 & 73.4 & 76.0 & 71.8 \\
\hline Mean (B) & 60.0 & 67.2 & 70.2 & & 62.7 & 69.6 & 72.2 & \\
\hline LSD $0.5 \%$ & A: 2.2 & B: 1.1 & B: 2.2 & & & $1.2 \quad \mathrm{~B}:$ & $\mathrm{AB}$ & 2.4 \\
\hline \multirow{4}{*}{$\begin{array}{l}\text { Vermicompost } \\
\text { Levels (A) }\end{array}$} & \multicolumn{8}{|c|}{ Chitosan nanoparticles concentrations (B) } \\
\hline & \multicolumn{8}{|c|}{ Branch number } \\
\hline & \multicolumn{4}{|c|}{ First season } & \multicolumn{4}{|c|}{ Second season } \\
\hline & Control & $20 \mathrm{ppm}$ & $40 \mathrm{ppm}$ & Mean $(\mathrm{A})$ & Control & $20 \mathrm{ppm}$ & $40 \mathrm{ppm}$ & Mean (A) \\
\hline Control & 8.5 & 9.2 & 10.0 & 9.2 & 8.9 & 9.8 & 10.7 & 9.8 \\
\hline 2 tons /feddan & 9.5 & 10.1 & 10.9 & 10.2 & 10.1 & 10.3 & 11.7 & 10.6 \\
\hline 4 tons /feddan & 9.8 & 10.4 & 11.3 & 10.4 & 10.4 & 11.3 & 12.2 & 11.3 \\
\hline 6 tons /feddan & 10.2 & 10.8 & 11.9 & 11.0 & 11.0 & 11.4 & 13.6 & 12.0 \\
\hline Mean (B) & 9.5 & 10.1 & 11.0 & & 10.1 & 10.7 & 12.1 & \\
\hline LSD $0.5 \%$ & & 0.7 & $\mathrm{AB}$ & 1.1 & & 0.7 & $\mathrm{AB}$ & 1.3 \\
\hline \multirow{4}{*}{$\begin{array}{l}\text { Vermicompost } \\
\text { Levels (A) }\end{array}$} & \multicolumn{8}{|c|}{ Chitosan nanoparticles concentrations (B) } \\
\hline & \multicolumn{8}{|c|}{ Herb fresh weight (g/plant) } \\
\hline & \multicolumn{4}{|c|}{ First season } & \multicolumn{4}{|c|}{ Second season } \\
\hline & Control & $20 \mathrm{ppm}$ & $40 \mathrm{ppm}$ & Mean $(\mathrm{A})$ & Control & $20 \mathrm{ppm}$ & $40 \mathrm{ppm}$ & Mean (A) \\
\hline Control & 42.3 & 45.4 & 49.8 & 45.8 & 46.9 & 50.1 & 52.7 & 49.9 \\
\hline 2 tons /feddan & 56.7 & 65.2 & 66.8 & 62.9 & 61.3 & 71.4 & 72.8 & 68.5 \\
\hline 4 tons /feddan & 69.6 & 73.1 & 75.2 & 72.6 & 68.3 & 76.9 & 77.8 & 74.3 \\
\hline 6 tons /feddan & 72.5 & 77.1 & 79.8 & 76.5 & 74.3 & 80.1 & 82.4 & 78.9 \\
\hline Mean (B) & 60.3 & 65.2 & 67.9 & & 62.7 & 69.6 & 71.4 & \\
\hline LSD $0.5 \%$ & & A: $1.4 \quad B:$ & $\mathrm{AB}$ : & & & 1.3 & $\mathrm{AB}$ & 3.2 \\
\hline \multirow{4}{*}{$\begin{array}{l}\text { Vermicompost } \\
\text { Levels (A) }\end{array}$} & \multicolumn{8}{|c|}{ Chitosan nanoparticles concentrations (B) } \\
\hline & \multicolumn{8}{|c|}{ Herb dry weight (g/plant) } \\
\hline & \multicolumn{4}{|c|}{ First season } & \multicolumn{4}{|c|}{ Second season } \\
\hline & Control & $20 \mathrm{ppm}$ & $40 \mathrm{ppm}$ & Mean (A) & Control & $20 \mathrm{ppm}$ & $40 \mathrm{ppm}$ & Mean (A) \\
\hline Control & 10.8 & 11.9 & 12.8 & 11.8 & 12.1 & 12.9 & 13.6 & 12.9 \\
\hline 2 tons /feddan & 14.7 & 16.8 & 17.7 & 16.4 & 15.7 & 18.1 & 18.9 & 17.6 \\
\hline 4 tons /feddan & 17.8 & 18.9 & 19.5 & 18.7 & 17.5 & 19.5 & 20.3 & 19.1 \\
\hline 6 tons /feddan & 18.6 & 19.8 & 21.1 & 19.8 & 19.2 & 20.7 & 22.2 & 20.7 \\
\hline Mean (B) & 15.5 & 16.9 & 17.8 & & 16.1 & 17.8 & 18.8 & \\
\hline LSD $0.5 \%$ & \multicolumn{2}{|c|}{$\mathrm{A}: 1.4$} & \multicolumn{2}{|c|}{ AB: 1.3} & \multicolumn{2}{|c|}{$\mathrm{A}: 1.5$} & \multicolumn{2}{|c|}{ AB: 1.8} \\
\hline
\end{tabular}

The efficiency of vermicompost in improving plant height, branch number, herb fresh weight (g/plant) and herb dry weight (g/plant) were indicated by Vadiraj et al. (1993) on cardamom (Elettaria cardamomum), Karmegam et al. (1999) on green gram, Atiyeh et al.
(2000) on pot marigold, Bongkyoon (2004) on Solanum tuberosum L., Pande et al. (2007) on Bacopa monnieri Ahmed et al. (2011) on Hibiscus sabdariffa L., Singh et al. (2012) on Coleus forskohlii, Aryafar et al. (2013) on Nigella sativa L and Al- Sayed et al. (2019) on roselle 
(Hibiscus sabdariffa L.). As for ChNP treatments, the listed data in Table (3) revealed that plant height, branch number, herb fresh weight (g/plant) and herb dry weight (g /plant) were significantly increased, in both seasons as a result of supplying the plants with these materials, except for $20 \mathrm{ppm}$ chitosan nanoparticles treatment in the second season, with respect to branch number comparing to control. Moreover, the most effective treatment was obtained by using $40 \mathrm{ppm}$ chitosan nanoparticles which increased these traits by 17.0 and 15.2, 15.8 and 19.8, 12.6 and 13.9 and 14.8 and by $16.8 \%$ in comparison with those obtained by other treatments and control. The positive effect of ChNP treatments on enhancing these characteristics was emphasized by Choi et al. (2000) on soybean, Khan et al. (2002) on maize and soybean, ElTantawy (2009) on Solanum lycopersicum, Farouk, et al. (2011) on radish (Raphanus sativus, L. var. sativus), Ma et al.(2011) on wheat, Mahdavi et al. (2011) on Safflower (Carthamustinctorius L.), Mahdavi and Rahimi (2013) on ajowan (Carum copticum), Massoud et al. (2016) on coriander and Dzung et al. (2017) on chili plant. The interaction between the two studied factors had significant effect on herb dry weight /plant in first and the second seasons. It was found that most combined treatments significantly affected plant height, branch number, herb fresh weight ( $\mathrm{g} /$ plant $)$ and herb dry weight ( $\mathrm{g} /$ plant) in comparison with untreated plants. Furthermore, the addition of vermicompost at the high level (6 tons /feddan) plus 40 ppm ChNP proved to be more effective than other combinations, as clearly declared in (Table 3).

\subsection{Yield parameters}

The presented data in Table (4) indicated that capsule number /plant, capsule weight /plant, seed weight (g/plant) and weight of 1000 seed /plant were significantly augmented, in the two seasons, due to using all levels of vermicompost as compared to unfertilized plants. The maximum capsules number /plant, capsule weight/plant, seed weight (g/plant) and weight of $1000 \mathrm{seed} /$ plant was noticed by utilizing the high level of vrmicompost as ranged 41.7 and 40.2, 42.1 and 39.9, 31.7 and 30.3 and 33.9 and $24.9 \%$ over the check treatment during the two experimental seasons, respectively. The capability of vermicompost application on enhancing yield components was emphasized by Jadhav et al. (1997) on sunflower (Helianthus annuиs L.), Vadiraj et al. (1998) on coriander (Coriandrum sativum), Reddy et al. (1998) on Chrysanthemum chinensis, Atiyeh et al., (2002) on some vegetables, Senthilkumar et al. (2004) on Rose sp, Nagavallemma et al. (2004) on mung bean (Vigna radiate L.), Alam et al. (2007) on red amaranth, Chamani et al. and (2008), Darzi et al. (2012) on anise (Pimpinella anisum L.), Bahrampour 
and Ziveh (2013) on tomato, Maji et al. (2016) on pea (Pisum sativum L.).

Table (4): Influence of vermicompost and chitosan nanoparticles on yield parameters of black cumin (Nigella sativa L.) plants during the seasons of 2018-2019 and 20192020 .

\begin{tabular}{|c|c|c|c|c|c|c|c|c|}
\hline \multirow{4}{*}{$\begin{array}{l}\text { Vermicompost } \\
\text { Levels (A) }\end{array}$} & \multicolumn{8}{|c|}{ Chitosan nanoparticles concentrations (B) } \\
\hline & \multicolumn{8}{|c|}{ Capsule number/plant } \\
\hline & \multicolumn{4}{|c|}{ First season } & \multicolumn{4}{|c|}{ Second season } \\
\hline & Control & $20 \mathrm{ppm}$ & $40 \mathrm{ppm}$ & Mean (A) & Control & $20 \mathrm{ppm}$ & $40 \mathrm{ppm}$ & Mean (A) \\
\hline Control & 45.7 & 53.2 & 54.4 & 51.1 & 50.9 & 56.3 & 60.7 & 56.0 \\
\hline 2 tons /feddan & 58.1 & 63.5 & 66.7 & 62.8 & 62.9 & 67.4 & 70.2 & 66.8 \\
\hline 4 tons /feddan & 63.7 & 68.1 & 71.5 & 67.8 & 66.4 & 73.9 & 77.7 & 72.7 \\
\hline 6 tons /feddan & 64.9 & 74.2 & 78.1 & 72.4 & 68.1 & 81.7 & 85.6 & 78.5 \\
\hline Mean (B) & 58.1 & 64.8 & 67.7 & & 62.1 & 69.8 & 73.6 & \\
\hline LSD $0.5 \%$ & A: 0.4 & B: 0.7 & B: 1.4 & & & $0.9 \quad$ B: & $\mathrm{AB}:$ & \\
\hline \multirow{4}{*}{$\begin{array}{l}\text { Vermicompost } \\
\text { Levels (A) }\end{array}$} & \multicolumn{8}{|c|}{ Chitosan nanoparticles concentrations (B) } \\
\hline & \multicolumn{8}{|c|}{ Capsule weight/plant } \\
\hline & \multicolumn{4}{|c|}{ First season } & \multicolumn{4}{|c|}{ Second season } \\
\hline & Control & $20 \mathrm{ppm}$ & $40 \mathrm{ppm}$ & Mean (A) & Control & $20 \mathrm{ppm}$ & $40 \mathrm{ppm}$ & Mean $(\mathrm{A})$ \\
\hline Control & 13.8 & 16.7 & 17.2 & 15.9 & 15.9 & 17.2 & 18.9 & 17.3 \\
\hline 2 tons /feddan & 18.1 & 19.8 & 20.8 & 19.6 & 19.1 & 20.9 & 21.8 & 20.6 \\
\hline 4 tons /feddan & 19.6 & 21.6 & 22.4 & 21.2 & 20.1 & 23.0 & 24.2 & 22.4 \\
\hline 6 tons /feddan & 19.9 & 23.5 & 24.4 & 22.6 & 20.6 & 25.5 & 26.4 & 24.2 \\
\hline Mean (B) & 17.9 & 20.4 & 21.2 & & 18.9 & 21.7 & 22.8 & \\
\hline LSD $0.5 \%$ & \multicolumn{4}{|c|}{$\begin{array}{lll}\text { A: } 1.0 & \text { B: } 0.9 & \text { AB: } 1.9 \\
\end{array}$} & \multicolumn{4}{|c|}{ A: 1.2 B: 1.0} \\
\hline \multirow{4}{*}{$\begin{array}{l}\text { Vermicompost } \\
\text { Levels (A) }\end{array}$} & \multicolumn{8}{|c|}{ Chitosan nanoparticles concentrations (B) } \\
\hline & \multicolumn{8}{|c|}{ Seed weight (g/plant) } \\
\hline & \multicolumn{4}{|c|}{ First season } & \multicolumn{4}{|c|}{ Second season } \\
\hline & Control & $20 \mathrm{ppm}$ & $40 \mathrm{ppm}$ & Mean (A) & Control & $20 \mathrm{ppm}$ & $40 \mathrm{ppm}$ & Mean $(\mathrm{A})$ \\
\hline Control & 18.1 & 20.7 & 21.0 & 19.9 & 19.6 & 21.4 & 22.4 & 21.1 \\
\hline 2 tons /feddan & 20.4 & 22.6 & 23.4 & 22.1 & 21.3 & 23.2 & 24.1 & 22.9 \\
\hline 4 tons /feddan & 22.1 & 23.3 & 25.1 & 23.5 & 22.5 & 24.9 & 26.2 & 24.5 \\
\hline 6 tons /feddan & 23.0 & 26.2 & 29.3 & 26.2 & 23.6 & 28.2 & 30.8 & 27.5 \\
\hline Mean $(\mathrm{B})$ & 20.9 & 23.2 & 24.7 & & 21.8 & 24.4 & 25.9 & \\
\hline LSD $0.5 \%$ & & $0.15 \quad \mathrm{~B}:$ & $.11 \mathrm{AB}:$ & .23 & & $0.10 \quad \mathrm{~B}$ & $.11 \mathrm{AB}$ : & .24 \\
\hline \multirow{4}{*}{$\begin{array}{l}\text { Vermicompost } \\
\text { Levels (A) }\end{array}$} & \multicolumn{8}{|c|}{ Chitosan nanoparticles concentrations (B) } \\
\hline & \multicolumn{8}{|c|}{ Thousand seeds weight/plant } \\
\hline & \multicolumn{4}{|c|}{ First season } & \multicolumn{4}{|c|}{ Second season } \\
\hline & Control & $20 \mathrm{ppm}$ & $40 \mathrm{ppm}$ & Mean (A) & Control & $20 \mathrm{ppm}$ & $40 \mathrm{ppm}$ & Mean (A) \\
\hline Control & 1.55 & 1.57 & 2.02 & 1.71 & 1.65 & 1.71 & 2.08 & 1.81 \\
\hline 2 tons /feddan & 1.80 & 2.00 & 2.16 & 1.99 & 1.70 & 2.07 & 2.12 & 1.96 \\
\hline 4 tons /feddan & 2.00 & 2.32 & 2.37 & 2.23 & 1.82 & 2.24 & 2.29 & 2.12 \\
\hline 6 tons /feddan & 1.96 & 2.44 & 2.46 & 2.29 & 1.84 & 2.37 & 2.57 & 2.26 \\
\hline Mean (B) & 1.83 & 2.08 & 2.25 & & 1.75 & 2.10 & 2.27 & \\
\hline LSD $0.5 \%$ & \multicolumn{4}{|c|}{$\mathrm{A}: 0.15 \quad \mathrm{~F}$} & \multicolumn{4}{|c|}{ A: 0.10} \\
\hline
\end{tabular}

With regard to chitosan nanoparticles (ChNP) treatments, the obtained results in Table (4) emphasized that foliar spray with chitosan nanoparticles at all concentrations, during the two seasons, caused a significant augment in capsule number /plant, capsule weight/plant, seed weight (g/plant) and weight of 1000 seed /plant comparing to control. Obviously, the application of $\mathrm{ChNP}$ at the high concentration (40 ppm) gave the highest values of these traits as ranged 16.5 and 18.5, 18.4 and 20.6, 18.2 and 18.8 and 22.9 and $29.7 \%$ over no sprayed ones in the first and second seasons, respectively. The augment in capsule number/plant, 
capsule weight /plant, seed weight (g /plant) and weight of $1000 \mathrm{seed} /$ plant due to applying ChNP was also demonstrated by Dzunga et al. (2011) on coffee, Abdel-Aziz et al. (2016) on wheat, Zagzog et al. (2017) on mango (Mangifera indica L.). Regarding the combination, the obtained results in Table (4) cleared a significant effect on capsules number /plant, capsule weight /plant, seed weight (g /plant) and weight of 1000 seed /plant, during the two experimental seasons. However, most of combined treatments caused a significant increment in these traits, during the two seasons, comparing to untreated plants. Therefore, adding vermicompost at 6 tons/feddan $+40 \mathrm{ppm}$ chitosan nanoparticles proved to be more effective in increasing capsule number /plant, capsule weight /plant, seed weight (g /plant) and weight of 1000 seed /plant than those of by other combinations.

\subsection{Oil production}

\subsubsection{Volatile oil and fixed oil percentages and their yield (ml/plant)}

The obtained results in Table (5) indicated that volatile oil and fixed oil \% and volatile oil and fixed oil yield ( $\mathrm{ml}$ /plant) of black cumin seeds was significantly increased as a result of vermicompost application at all levels compared to the check treatment, during the two consecutive seasons. Clearly, the use of vermicompost at the high level (6 tons /feddan) gave the highest values of volatile oil \& fixed oil \% and volatile oil and fixed oil yield ( $\mathrm{ml} / \mathrm{plant}$ ) comparing to other treatments. This treatment augmented such traits by 49.3 and 49.4 , 23.0 and $21.3 \% 98.1$ and 99.4 and 70.6 and $65.6 \%$ over the check treatment in the two seasons, respectively. The role of vermicompost in enhancing volatile oil \& fixed oil $\%$ and volatile oil and fixed oil yield ( $\mathrm{ml} /$ plant) was reported by Hadi et al. (2011) on Matricaria chamomila L., Singh (2011) on coriander (Coriandrum sativum L.), Moslemi et al. (2012) on Coriander (Coriandrum sativu L.), Singh and Wasnik (2013) on rosemary (Rosmarinus officinalis $\quad$ L.) and Abbaszadeh et al. (2016) on Lavandula officinalis. It is evident from the revealed data in Table (5) that volatile oil \& fixed oil $\%$ and volatile oil \& fixed oil yield (ml/plant) of black cumin was statistically significant, in both seasons, due to applying ChNP treatments as compared to untreated ones during the two experimental seasons. Clearly spraying the plants by $40 \mathrm{ppm}$ ChNP yielded the maximum values of volatile oil and fixed oil $\%$ and volatile oil and fixed oil yield ( $\mathrm{ml} / \mathrm{plant}$ ) by range 24.2 and 29.8, 8.9 and10.3, 49.2 and 57.4 and 26.7 and $39.3 \%$ in the first and second seasons, respectively. Accordingly, the combination of the two studied factors on volatile oil and fixed oil $\%$ and volatile oil and fixed oil yield (ml/plant) of black cumin had significant effect during the two experimental seasons (Table 5). From the recorded data, it could be noticed that applying most combined treatments significantly increased these 
traits, in the first and second seasons, as compared to control. Clearly, the application of vermicompost at the high level (6 tons /feddan) with $40 \mathrm{ppm}$ chitosan nanoparticles proved to be more effective in increasing volatile oil \& fixed oil $\%$ and volatile oil \& fixed oil yield ( $\mathrm{ml} /$ plant) than those obtained by other combination treatments in both seasons.

Table (5): Influence of vermicompost and chitosan nanoparticles on volatile \& fixed oil\% and volatile \& fixed oil yield ( $\mathrm{ml} /$ plant) of black cumin (Nigella sativa L.) plants during the seasons of 2018-2019 and 2019-2020.

\begin{tabular}{|c|c|c|c|c|c|c|c|c|}
\hline \multirow{4}{*}{$\begin{array}{l}\text { Vermicompost } \\
\text { Levels (A) }\end{array}$} & \multicolumn{8}{|c|}{ Chitosan nanoparticles concentrations (B) } \\
\hline & \multicolumn{8}{|c|}{ Volatile oil (\%) } \\
\hline & \multicolumn{4}{|c|}{ First season } & \multicolumn{4}{|c|}{ Second season } \\
\hline & Control & $20 \mathrm{ppm}$ & $40 \mathrm{ppm}$ & Mean $(\mathrm{A})$ & Control & $20 \mathrm{ppm}$ & $40 \mathrm{ppm}$ & Mean (A) \\
\hline Control & 0.74 & 0.79 & 0.85 & 0.79 & 0.77 & 0.82 & 0.91 & 0.83 \\
\hline 2 tons /feddan & 0.90 & 1.08 & 1.11 & 1.03 & 0.96 & 1.24 & 1.28 & 1.16 \\
\hline 4 tons /feddan & 0.96 & 1.17 & 1.23 & 1.12 & 1.00 & 1.24 & 1.29 & 1.18 \\
\hline 6 tons /feddan & 1.02 & 1.19 & 1.34 & 1.18 & 1.04 & 1.26 & 1.41 & 1.24 \\
\hline Mean (B) & 0.91 & 1.06 & 1.13 & & 0.94 & 1.14 & 1.22 & \\
\hline LSD $0.5 \%$ & A: 0.04 & B: 0.05 & AB: 0.16 & & A: 0.04 & B: 0.06 & B: 0.19 & \\
\hline \multirow{4}{*}{$\begin{array}{l}\text { Vermicompost } \\
\text { Levels (A) }\end{array}$} & \multicolumn{8}{|c|}{ Chitosan nanoparticles concentrations (B) } \\
\hline & \multicolumn{8}{|c|}{ Fixed oil $(\%)$} \\
\hline & \multicolumn{4}{|c|}{ First season } & \multicolumn{4}{|c|}{ Second season } \\
\hline & Control & $20 \mathrm{ppm}$ & $40 \mathrm{ppm}$ & Mean (A) & Control & $20 \mathrm{ppm}$ & $40 \mathrm{ppm}$ & Mean (A) \\
\hline Control & 23.33 & 24.30 & 25.73 & 24.45 & 23.51 & 25.70 & 26.70 & 25.30 \\
\hline 2 tons /feddan & 24.73 & 25.67 & 26.77 & 25.72 & 25.63 & 26.17 & 27.73 & 26.51 \\
\hline 4 tons /feddan & 26.91 & 28.03 & 28.33 & 27.76 & 27.07 & 28.30 & 29.07 & 28.15 \\
\hline 6 tons /feddan & 28.37 & 30.10 & 31.51 & 29.99 & 28.83 & 30.61 & 32.63 & 30.69 \\
\hline Mean (B) & 25.84 & 27.03 & 28.09 & & 26.26 & 27.70 & 29.03 & \\
\hline LSD $0.5 \%$ & A: 0.35 & B: 0.48 & B: 0.97 & & A: 0.32 & B: $0.64 A$ & B: 1.28 & \\
\hline \multirow{4}{*}{$\begin{array}{l}\text { Vermicompost } \\
\text { Levels (A) }\end{array}$} & \multicolumn{8}{|c|}{ Chitosan nanoparticles concentrations (B) } \\
\hline & \multicolumn{8}{|c|}{ Volatile oil yield (ml/plant) } \\
\hline & \multicolumn{4}{|c|}{ First season } & \multicolumn{4}{|c|}{ Second season } \\
\hline & Control & $20 \mathrm{ppm}$ & $40 \mathrm{ppm}$ & Mean (A) & Control & $20 \mathrm{ppm}$ & $40 \mathrm{ppm}$ & Mean (A) \\
\hline Control & 0.134 & 0.162 & 0.178 & 0.158 & 0.140 & 0.175 & 0.203 & 0.173 \\
\hline 2 tons /feddan & 0.183 & 0.244 & 0.260 & 0.229 & 0.205 & 0.287 & 0.308 & 0.267 \\
\hline 4 tons /feddan & 0.212 & 0.272 & 0.309 & 0.264 & 0.226 & 0.309 & 0.338 & 0.291 \\
\hline 6 tons /feddan & 0.234 & 0.312 & 0.394 & 0.313 & 0.246 & 0.355 & 0.434 & 0.345 \\
\hline Mean (B) & 0.191 & 0.248 & 0.285 & & 0.204 & 0.282 & 0.321 & \\
\hline LSD $0.5 \%$ & A: 0.017 & B: 0.023 & AB: 0.049 & & A: 0.023 & B: 0.024 & AB: 0.052 & \\
\hline \multirow{4}{*}{$\begin{array}{l}\text { Vermicompost } \\
\text { Levels (A) }\end{array}$} & \multicolumn{8}{|c|}{ Chitosan nanoparticles concentrations (B) } \\
\hline & \multicolumn{8}{|c|}{ Fixed oil yield (ml/plant) } \\
\hline & \multicolumn{4}{|c|}{ First season } & \multicolumn{4}{|c|}{ Second season } \\
\hline & Control & $20 \mathrm{ppm}$ & $40 \mathrm{ppm}$ & Mean $(\mathrm{A})$ & Control & $20 \mathrm{ppm}$ & $40 \mathrm{ppm}$ & Mean (A) \\
\hline Control & 4.223 & 5.023 & 5.412 & 3.119 & 4.237 & 5.512 & 5.991 & 3.279 \\
\hline 2 tons /feddan & 5.053 & 5.807 & 6.254 & 3.705 & 5.458 & 6.068 & 6.672 & 4.168 \\
\hline 4 tons /feddan & 5.962 & 6.542 & 7.121 & 4.727 & 6.096 & 7.046 & 7.606 & 4.734 \\
\hline 6 tons /feddan & 6.524 & 7.886 & 9.244 & 5.321 & 6.796 & 8.627 & 10.042 & 5.430 \\
\hline Mean (B) & 3.692 & 4.284 & 4.678 & & 3.575 & 4.655 & 4.979 & \\
\hline LSD $0.5 \%$ & \multicolumn{4}{|c|}{ A: $0.319 \quad$ B:0.384 AB: 0.769} & \multicolumn{4}{|c|}{ A: 0.492 B: $0.414 \quad$ AB: 0.828} \\
\hline
\end{tabular}

\subsection{Chemical constituent parameters}

\subsubsection{Nitrogen, phosphorus and potassium (\%)}

The presented data in Table (6) showed that the nutrient elements of $\mathrm{N}, \mathrm{P}$ and $\mathrm{K}$ $\%$ in black cumin herb were significantly augmented due to the use of vermicompost treatments as compared to unfertilized plants for the two 
experimental seasons. It is noticed that supplying the plants with vermicompost at the high rate (6 tons /feddan) gave the maximum values of the three examined elements of $\mathrm{N}, \mathrm{P}$ and $\mathrm{K} \%$ in both seasons, which increased $\mathrm{N} \%$ by 58.3 and by $55.9 \%$, augmented $\mathrm{P} \%$ by 28.1 and by $26.9 \%$ and also increased $\mathrm{K} \%$ by 16.4 and by $18.7 \%$ over the check treatment during the two seasons, respectively. The promoting effect of vermicompost treatments was reported by Sainz et al. (1998) on rice (Oryza sativa L.), Premuzic et al. (1998) on petunia (Petunia hybrida L.), Senthilkumar et al. (2004) on Rose sp., Kumari and Ushakumari (2002) on cowpea (Vigna unguiculata L. Walp), Llaven (2008) on bell pepper, Lazcano and Dominguez (2010) on ornamental plant species and Manh and Wang (2013) on Cucumis melo L.

Table (6): Influence of vermicompost and chitosan nanoparticles on NPK percentages in the dry herb of black cumin (Nigella sativa L) plants during the seasons of 20182019 and 2019-2020.

\begin{tabular}{|c|c|c|c|c|c|c|c|c|}
\hline \multirow{4}{*}{$\begin{array}{l}\text { Vermicompost } \\
\text { Levels (A) }\end{array}$} & \multicolumn{8}{|c|}{ Chitosan nanoparticles concentrations (B) } \\
\hline & \multicolumn{8}{|c|}{ Nitrogen $(\%)$} \\
\hline & \multicolumn{4}{|c|}{ First season } & \multicolumn{4}{|c|}{ Second season } \\
\hline & Control & $20 \mathrm{ppm}$ & $40 \mathrm{ppm}$ & Mean $(\mathrm{A})$ & Control & $20 \mathrm{ppm}$ & $40 \mathrm{ppm}$ & Mean (A) \\
\hline Control & 1.33 & 1.39 & 1.46 & 1.39 & 1.38 & 1.42 & 1.49 & 1.43 \\
\hline 2 tons /feddan & 1.48 & 1.53 & 1.57 & 1.53 & 1.54 & 1.58 & 1.61 & 1.58 \\
\hline 4 tons /feddan & 1.68 & 1.76 & 1.87 & 1.77 & 1.63 & 1.73 & 1.88 & 1.75 \\
\hline 6 tons /feddan & 2.02 & 2.18 & 2.40 & 2.20 & 2.03 & 2.22 & 2.43 & 2.23 \\
\hline Mean $(\mathrm{B})$ & 1.63 & 1.72 & 1.83 & & 1.65 & 1.74 & 1.85 & \\
\hline LSD $0.5 \%$ & A: 0.06 & B: 0.07 & AB: 0.18 & & A: 0.06 & B: 0.07 & B: 0.18 & \\
\hline \multirow{4}{*}{$\begin{array}{l}\text { Vermicompost } \\
\text { Levels (A) }\end{array}$} & \multicolumn{8}{|c|}{ Chitosan nanoparticles concentrations (B) } \\
\hline & \multicolumn{8}{|c|}{ Phosphorus (\%) } \\
\hline & \multicolumn{4}{|c|}{ First season } & \multicolumn{4}{|c|}{ Second season } \\
\hline & Control & $20 \mathrm{ppm}$ & $40 \mathrm{ppm}$ & Mean (A) & Control & $20 \mathrm{ppm}$ & $40 \mathrm{ppm}$ & Mean (A) \\
\hline Control & 0.266 & 0.332 & 0.342 & 0.313 & 0.272 & 0.337 & 0.347 & 0.319 \\
\hline 2 tons /feddan & 0.356 & 0.361 & 0.370 & 0.362 & 0.350 & 0.354 & 0.364 & 0.356 \\
\hline 4 tons /feddan & 0.363 & 0.378 & 0.387 & 0.376 & 0.369 & 0.381 & 0.403 & 0.384 \\
\hline 6 tons /feddan & 0.392 & 0.403 & 0.409 & 0.401 & 0.393 & 0.407 & 0.414 & 0.405 \\
\hline Mean $(\mathrm{B})$ & 0.344 & 0.369 & 0.377 & & 0.346 & 0.370 & 0.382 & \\
\hline LSD $0.5 \%$ & A: 0.016 & B: 0.016 & AB: 0.032 & & A: 0.016 & B: 0.017 & B: 0.035 & \\
\hline \multirow{4}{*}{$\begin{array}{l}\text { Vermicompost } \\
\text { Levels (A) }\end{array}$} & \multicolumn{8}{|c|}{ Chitosan nanoparticles concentrations (B) } \\
\hline & \multicolumn{8}{|c|}{ Potassium $(\%)$} \\
\hline & \multicolumn{4}{|c|}{ First season } & \multicolumn{4}{|c|}{ Second season } \\
\hline & Control & $20 \mathrm{ppm}$ & $40 \mathrm{ppm}$ & Mean (A) & Control & $20 \mathrm{ppm}$ & $40 \mathrm{ppm}$ & Mean (A) \\
\hline Control & 1.24 & 1.27 & 1.32 & 1.28 & 1.21 & 1.23 & 1.26 & 1.23 \\
\hline 2 tons /feddan & 1.29 & 1.40 & 1.43 & 1.37 & 1.26 & 1.35 & 1.40 & 1.34 \\
\hline 4 tons /feddan & 1.33 & 1.45 & 1.50 & 1.43 & 1.32 & 1.43 & 1.46 & 1.40 \\
\hline 6 tons /feddan & 1.37 & 1.52 & 1.57 & 1.49 & 1.35 & 1.49 & 1.55 & 1.46 \\
\hline Mean (B) & 1.31 & 1.41 & 1.46 & & 1.29 & 1.38 & 1.42 & \\
\hline LSD $0.5 \%$ & A: 0.02 & $\mathrm{~B}: 0.03 \quad \mathrm{~A}$ & B: 0.09 & & A: 0.03 & B: $0.03 \quad A$ & $: 0.10$ & \\
\hline
\end{tabular}

Data in Table (6) indicated that the percentages of $\mathrm{N}, \mathrm{P}$ and $\mathrm{K}$ in dry herb of black cumin were significantly augmented due to the use of ChNP treatments comparing to untreated treatment in the two concoctive seasons.
In this regard, the maximum values of the three tested elements of $\mathrm{N}, \mathrm{P}$ and $\mathrm{K} \%$ were obtained by applying 40 ppm ChNP concentration without significant differences between the two superior treatments, in the first and the second 
seasons, respectively. The positive effect of ChNP treatments on the elements of $\mathrm{N}$, $\mathrm{P}$ and $\mathrm{K} \%$ was insured by Dzunga et al. (2011) on coffee, Zagzog (2017) on mango (Mangifera indica L.). Regarding the combined between the vermicompost manure and chitosan nanoparticles (ChNP) treatments, the result in Tables (6-8) revealed that it was significant effect on the three studied elements N, P and $\mathrm{K} \%$ for the two experimental seasons. However, the most effective treatments were vermicompost at the high level (6 tons /feddan) plus $40 \mathrm{ppm}$ chitosan nanoparticles concerning $\mathrm{N}, \mathrm{P}$ and $\mathrm{K} \%$ in comparison with other combined treatments in both seasons. From the obtained data, it could be discussed as follows: the improvement of plant height, branch number, herb fresh weight, herb dry weight, number of capsule and weight, seed weight, 1000 seed weight, fixed and volatile oil percentages and yields of seed of black cumin in this study as a result of using organic manure (vermicompost) reflected the biological and physiological roles of organic fertilization which was explained that organic matter as a source of elements namely, N, P and $\mathrm{K}$ as well as, it is considered as a source of energy for the growth of microorganisms. Dominguez (2004) showed that vermicompost is a nutrient rich (macro and micronutrients.), microbiologically active. It is a stabilized, finely divided peat-like material with a low C:N ratio, high porosity, a slow release and high-water holding capacity, in which most nutrients are present in forms that are readily taken up by plants. Anwar et al. (2005) studied the effect of vemicompost on growth and productivity of some medicinal and aromatic plant and showed that positive effects due to the use of vermicompost. Darzi et al. (2012) showed that, the using of vermicompost at (0, 5 and 10 tons /ha) significantly affected on plant height, umbel number per plant, biological and seed yield of anise. The maximum values of these traits were obtained by vermicompost at 10 tons/ha. Also, the enhancement of the previous traits in the present work might be attributed to the biological and physiological roles of chitosan may stimulate a signal to synthesize plant hormones such as gibberellins. In addition to chitosan may enhance growth and development by some signalling pathway related to auxin biosynthesis via a tryptophan- independent pathway Uthairatanakij et al. (2007). Moreover, chitosan has been shown to stimulate plant growth (Kim, 2005; Mondal et al., 2012), to possess antioxidant activity (Chen et al., 2009; Xie et al., 2001). Van et al. 2013 showed that ChNP was impacted on the biophysical characteristics of coffee seedlings, through increasing pigment content, the rate of photosynthesis and nutrient uptake. It could be recommended to supply black cumin plants with vermicompost at 6 tons /feddan in combination with $40 \mathrm{ppm}$ ChNP for improving plant height, branch number, herb fresh weight, herb dry weight, capsule number and weight, seed weight, 1000 seed weight, fixed and volatile oil percentages and yields of the seeds.

\section{References}

AOAC (1970), Official methods of analysis association of official 
Agricultural chemists, $11^{\text {th }}$ Edition, The Association of Official Analytical Chemists, Washington, D.C., USA.

Abbaszadeh, B., Mavandi, P. and Mirza, M. (2016), "Dry Matter and Essential Oil Yield Changes of Lavandula officinalis under Cowmanure and Vermicompost Application", Journal of Medicinal Plants and By-products, Vol. 1, pp. 97-104.

Abdel-Aziz, H. M. M., Hasaneen, M. N. A. and Omer, A. A. (2016), "Nano chitosan-NPK fertilizer enhances the growth and productivity of wheat plants grown in sandy soil", Spanish Journal of Agricultural Research, Vol. 14 No. 1, pp. 9.

Ahmed, Y. M., Shalaby, E. A. and Shanan Nermeen, T. (2011), "The use of organic and inorganic cultures in improving vegetative growth, yield characters and antioxidant activity of roselle plants (Hibiscus sabdariffa L.)", African Journal of Biotechnology, Vol. 10 No. 11, pp. 1988 - 1996.

Al-Sayed, H. M., Hegab, S. A. Youssef, M. A. and Khalafalla, M. Y. (2019), "Integrated Effect of inorganic and organic nitrogen sources on growth and yield of roselle (Hibiscus sabdariffa L.)", Assiut Journal of Agriculture Science, Vol. 50 No. 3, pp. 164-183.

Alam, M. N., Jahan, M. S., Ali, M. K., Islam M. S. and Khandaker, S. M.
A. T. (2007), "Effect of vermicompost and NPKS Fertilizers on growth, yield and yield components of red amaranth", Australian Journal of Basic and Applied Sciences, Vol. 1 No. 4, pp. 706-716.

Anwar, M., Patra, D. D., Chand, S., Kumar, A., Naqvi, A. A. and Khanuja, S. P. S. (2005), "Effect of organic manures and inorganic fertilizer on growth, herb and oil yield, nutrient accumulation, and oil quality of French basil", Communications in Soil Science and Plant Analysis, Vol. 36, pp. 17371746.

Arancon, N. Q., Edwards, C. A., Babenko, A., Cannon, J., Galvis, P. and Metzger, J. D. (2008), "Influences of vermicomposts, produced by earthworms and microorganisms from cattle manure, food waste and paper waste, on the germination, growth and flowering of petunias in the greenhouse", Applied Soil Ecology, Vol. 39, pp. 91-99.

Aryafar, S., Sirousmehr, A., Najafi, R. S., Zadeh, M. M. H. and Aryafar, S. (2013), "Effects of Municipal Compost on Yield and Some Quantitative and Qualitative Characteristics of Nigella Sativa under Drought Stress", International Journal of Science and Engineering Investigations, Vol. 2 No. 12, pp. 2251-8843.

Atiyeh R., Lee, S., Edwards, C., 
Arancon, Q., Metzger, J. (2002), "The influence of humic acids derived from earthworm processed organic wastes on plant growth", Bioresource Technology, Vol. 84 No. 1, pp. 7-14.

Atiyeh, R. M., Edwards, C. A., Subler, S. and Metzger, J. D. (2000), "Earthworm processed organic wastes as components of horticultural potting media for growing marigolds and vegetable seedlings", Compost Science \& Utilization, Vol. 8, pp. 215-233.

Auffan, M., Rose, J., Bottero, J. Y., Lowry, G. V., Jolivet, J. P. and Wiesner, M. R. (2009), "Towards a definition of inorganic nanoparticles from an environmental, health and safety perspective", Nature Nanotechnology, Vol. 4, pp. 634664.

Bahrampour, T. and Ziveh, P. S. (2013), "Effect of vermicompost on tomato (Lycopersicum esculentum) fruits", International Journal of Agronomy and Plant Production, Vol. 4 No. 11, pp. 2965-2971.

Bashandy, S. A. E. (1996), "Effect of (Nigella sativa L.) oil on liver and kidney function of adult and senile rats", Egyptian Journal of Pharmaceutical Science, Vol. 37, pp. 313-327.

Bongkyoon, K. (2004), "Effect of vermicompost on growth of fallcropping potato in volcanic ash soil", Korean Journal Crop Science,
Vol. 49 No. 4, pp. 305-308.

Burits, M. and Bucar, F. (2000), "Antioxidant activity of Nigella sativa essential oil", Phytotherapy Research, Vol. 14, pp. 323-328.

Chamani, E., Joyce, D. C., Reihanytabar, A. (2008), "Vermicompost effects on the growth and flowering of Petunia hybrida 'Dream Neon Rose'", American-Eurasian Journal of Agricultural \& Environmental Sciences, Vol. 3 No. 3, pp. 506-512.

Chandrkrachang, S. (2002), "The application of chitin and chitosan in agriculture in Thailand", Advances in Chitin Science, Vol. 5, pp. 458462 .

Chen, W. G., Liu, X. and Chen, H. X. (2009), Preparation of modified chitosan with quaternary ammonium salt, Textile Bioengineering and Informatics Symposium Proceedings, Vol. 1, pp. 226-230.

Choi, H. D., Kim, S. S., Kim, K. T., Lee, J. Y. and Park, W. M. (2000), "Effect of presoaking treatments on growth and rot of soybean sprouts", Korean Journal of Food Science and Technology, Vol. 32, pp. 584-589.

Chapman, H. D. and Pratt, P. F. (1975), "Methods of Analysis for Soil, Plant and Water", Division of Agriculture Science, University of California, USA, pp.172-174.

Cottenie, A., Verloo, M., Velghe, M. and Camerlynck, R. (1982), Chemical 
Analysis of Plant and Soil, Laboratory of Analytical and Ayro Chemistry, State University of Ghent, Belgium.

Cristina, L. and Jorge, D. (2011), The use of vermicompost in sustainable agriculture: impact on plant growth and soil fertility, Nova Science Publishers, USA.

Darzi, M. T., Seyedhadi, M. H. and Rejali, F. (2012), "Effects of the application of vermicompost and phosphate solubilizing bacterium on the morphological traits and seed yield of anise (Pimpinella anisum L.)", Journal of Medicinal Plants Research, Vol. 6 No. 2, pp. 215219.

Dominguez, J. (2004), "State-of-the art and new perspectives on vermicomposting research", In: Edwards, C. A. (Ed.), Earthworm Ecology, $2^{\text {nd }}$ Edition, CRC Press, USA, pp. 401-424.

Duhan, J. S., Kumara, R., Kumara, N., Kaura, P., Nehrab, K. and Duhan, S. (2017), "Nanotechnology: The new perspective in precision agriculture", Biotechnology Reports, Vol. 15 No. 3, pp. 11-23.

Dzunga, N. A., Khanhb V. P. and Dzungc, T. T. (2011), "Research on impact of chitosan oligomers on biophysical characteristics, growth, development and drought resistance of coffee", Carbohydrate Polymers, Vol. 84 No. 8, pp. 751-755.
El-Tantawy, E. M. (2009), "Behaviour of tomato plants as affected by spraying with chitosan and aminofort as natural stimulator substances under application of soil organic amendments", Pakistan Journal Biological Science, Vol. 12, pp. 1164-1173.

Farouk S., Mosa, A. A., Taha, A. A., Ibrahim, H. M. and. EL-Gahmery, A. M. (2011), Protective Effect of humic acid and chitosan on radish (Raphanus sativus L. var. sativus) plants subjected to cadmium stress", Journal of Stress Physiology \& Biochemistry, Vol. 7 No. 2, pp. 99 116.

Goreja, W.G. (2003), Black seed nature's miracle remedy, NY 7 Amazing Herbs Press, New York, USA.

Guenther, E. (1961), The Essential Oils, Vol. 4, D. Van Nostrand Company, New York, USA, pp. 236.

Hadi, M. R. H. S., Darz, M. T., Ghandehari, Z. and Riazi, G. (2011), "Effects of vermicompost and amino acids on the flower yield and essential oil production from Matricaria chamomila L", Journal of Medicinal Plants Research, Vol. 5 No. 23, pp. 5611-5617.

Houghton, P. J., Zarka, R., De-LasHeras, B. and Hoult, J. R. (995), "Fixed oil of (Nigella sativa L.) and derived thymoquinone inhibition eicosanoid generation in leukocytes and membrane lipid peroxidation", Plant of medicine, Vol. 61 No. 1, pp. 
$33-36$.

Ingle, A., Gade, A., Pierrat, S., Sonnichsen, C. and Rai, M. (2008), "Mycosynthesis of silver nanoparticles using the fungus fusarium acuminatum and its activity against some human pathogenic bacteria", Current Nanoscience, Vol. 4 No. 2, pp. 141144.

Jadhav, A. D., Talashilkar, S. C. and Pawar, A. G. (1997), "Influence of the conjunctive use of FYM, vermicompost and urea on growth and nutrient uptake in rice", Journal of Maharashtra Agriculture University, Vol. 22 No. 2, pp. 249250.

Karmegam, N., Alagumalai, K. and Daniel, T. (1999), "Effect of vermicompost on the growth and yield of green gram (Phaseolus aureus Roxb.)", Tropical Agriculture, Vol. 76, pp. 143-146.

Khan, W. M., Prithiviraj, B. and Smiyh, D. L. (2002), "Effect of foliar application of chitin oligosaccharides on photosynthesis of maize and soybean", Photosynthetica, Vol. 40, pp. 621624.

Kim, H. J. (2005), Characterization of bioactive compounds in essential oils, fermented anchovy sauce, and edible plants, and induction of phytochemicals from edible plants using methyl jasmonate (MeJA) and chitosan, Ph.D. Thesis, Clemson
University, USA, pp. 178.

Kumar, A. (2005), Verms and Vermitechnology, APH Publishing Corporation, New Delhi, India.

Kumari, M. S. and Ushakumari, K. (2002), "Effect of vermicompost enriched with rock phosphate on the yield and uptake of nutrients in cowpea (Vigna unguinculata L. Walp)", Journal of Tropical Agriculture, Vol. 40, pp. 27-30.

Lazcano, C. and Dominguez, J. (2010), "Effects of vermicompost as a potting amendment of two commercially-grown ornamental plant species", Spanish Journal of Agricultural Research, Vol. 8 No. 4, pp. 1260-1270.

Llaven, M. A. O. (2008), "Fruit Characteristics of Bell Pepper Cultivated in Sheep Manure Vermicompost Substituted Soil", Journal of Plant Nutrition, Vol. 3, pp. 1585-1598.

Ma, L., Li, Y., Yu, C., Wang, Y., Li, X., Li, N., Chen, Q. and Bu, N. (2011), "Alleviation of exogenous oligochitosan on wheat seedlings growth under salt stress", Protoplasma, Vol. 249, pp. 393 399.

Mahdavi, B. and Rahimi, A. (2013), "Seed priming with chitosan improves the germination and growth performance of ajowan (Carum copticum) under salt stress", EurAsian Journal of BioSciences, 
Vol. 7, pp. 69-76.

Mahdavi, B., Sanavy, S. A. M. M., Aghaalikhani1, M., Sharifi, M. and Dolatabadian, A. (2011), "Chitosan improves osmotic potential tolerance in safflower (Carthamus tinctorius L.) seedlings", Journal of Crop Improvement, Vol. 25 No. 11, pp. 728-741.

Maji, D., Misra, P., Singh, S. and Kalra, A. (2016), "Humic acid rich vermicompost promotes plant growth by improving microbial community structure of soil as well as root nodulation and mycorrhizal colonization in the roots of Pisum sativum", Applied Soil Ecology, Vol. 110, pp. 97-108.

Manh, V. O. H. and Wang, C. H. O. (2013), "Vermicompost as an Important Component in Substrate: Effects on Seedling Quality and Growth of Muskmelon (Cucumis melo L.)", $4^{\text {th }} \quad$ International Conference on Agriculture and Animal Science (CAAS 2013), APCBEE Procedia, Vol. 8, pp. 3240.

Mondal, M. M. A., Malek, M. A., Puteh, A. B., Ismail, M. R., Ashrafuzzaman, M. and Naher, L. (2012), "Effect of foliar application of chitosan on growth and yield in okra", Australian Journal of Crop Science, Vol. 6 No. 5, pp. 918-921.

Moslemi, M., Abdolhossein, A., Hasanzade, H. and Hosseini, M. (2012), "Evaluation the effects of different levels of vermicompost on yield and yield components of coriander (Coriandrum sativum L.)", Annals Biological Research, Vol. 3, pp. 4852-4853.

Nagavallemma, K. P., Wani, S. P., Lacroix, S., Padmaja, V. V., Vineela, C., Babu Rao M. and Sahrawat, K. L. (2004), Vermicomposting: Recycling wastes into valuable organic fertilizer, Global Theme on Agrecosystems, Report no. 8. Patancheru 502 324, Andhra Pradesh, International Crops Research Institute for the Semi-Arid Tropics, India, pp. 20.

Pande, P., Chand, S., Yadav, V., Anwar, M. and Patra, D. D. (2007), "Influence of chromium with vermicompost on growth and accumulation by Brahmi", Communications in Soil Science and Plant Analysis, Vol. 38 No. 10, pp. 2815-2829.

Peniston, Q. P. and Johnson, E. (1980), "Process for the manufacture of chitosan". US Patent No. 4, 195, 175, USA, pp 5.

Premuzic, Z., Bargiela, M., Garcia, A., Rendina, A., Iorio, A. (1998), "Calcium, iron, potassium, phosphorus and vitamin $\mathrm{C}$ content of organic and hydroponic tomatoes", Horticulture of Science, Vol. 33, pp. 255-257.

Ramesh, P., Singh, M., and Rao, S. A. (2005), "Organic Farming: It's relevance to the Indian Contex", 
Current Science, Vol. 88 No. 4, pp. 561-568.

Reddy, A. V., Singh, R. P. (1998), "Fumigant toxicity of neem Azadirachta indica Juss. seed oil volatiles against pulse beetle, Callosobruchus maculatus Fab. Coleoptera: Bruchidae", Journal of Applied Entomology, 122: 601-611

Sainz, M. J., Taboada-Castro, M. T., Vilarino, A. (1998), "Growth, mineral nutrition and mycorrhizal colonization of red clover and cucumber plants grown in a soil amended with composted urban wastes", Plant Soil, Vol. 205, pp. 85-92.

Salomi, M. J. and Rajgopalar, K. R. (1989), "Anticancer Activity of (Nigella sativa L.)", Ancient Science of Life, Vol. 8, pp. 262-266.

Senthilkumar, S., Sriramachandrasekharan, M. V. and Haripriya, K. (2004), Effect of vermicompost and fertilizer on the growth and yield of rose", Journal of Interacademicia, Vol. 8, pp. 207210.

Singh, M. and Wasnik, K. (2014), "Effect of vermicompost and chemical fertilizer on growth, herb, oil yield, nutrient uptake, soil fertility, and oil quality of rosemary", Communications in Soil Science and Plant Analysis, Vol. 44 No. 7, pp. 2691-2700.

Singh, M. (2011), "Effect of vermicompost and chemical fertilizers on growth, yield and quality of coriander (Coriandrum sativum L.) in a semi-arid tropical climate", Journal of Spices and Aromatic Crops, Vol. 20 No. 1, pp. 30-33.

Singh, M. and Wasnik, K. (2013), "Effect of vermicompost and chemical fertilizer on growth, herb, oil yield, nutrient uptake, soil fertility, and oil quality of Rosemary", Communications in Soil Science and Plant Analysis, Vol. 44 No. 18, pp. 2691-2700

Singh, R., Soni, S. K., Awasthi, A. and Kalra, A. (2012), "Evaluation of vermicompost doses for management of root-rot disease complex in Coleus forskohlii under organic field conditions", Australasian Plant Pathology, Vol. 41, pp. 397-403.

Steel, R. G. D. and Torrie, J. H. (1986), Principle and Procedure of Statistics: A Biometrical Approach, $2^{\text {nd }}$ ed., McGraw-Hill Book Co., New York, USA.

Sugiyama, H., Hisamichi, K., Sakai, K., Usui, T., Ishiyama, J. I., Kudo, H., Ito, H. and Senda, Y. (2001), "The conformational study of chitin and chitosan oligomers in solution", Bioorganic and Medicinal Chemistry, Vol. 9, pp. 211-216.

Tilman, D., Cassman, K.G., Matson, P. A., Naylor, R. and Polasky, S. (2002), "Agricultural sustainability 
and intensive production practices", Nature, Vol. 418, pp. 671-677.

Ustun, G., Kent, L., Cekin, N. and Civelekoglu, H. (1990), Investigation of the technological properties of Nigella sativa, L. (black cumin) seed oil", Journal of the American Oil Chemists' Society, Vol. 67 No. 12, pp. 71-86.

Uthairatanakij, A., Jaime, A. Silva, T. D. and Obsuwan, K. (2007), "Chitosan for improving orchid production and quality", Orchid Science and Biotechnology, Vol. 1 No. 1, pp. 15.

Vadiraj, B. A., Siddagangaiah, D. and Potty, S. N. (1998), "Response of coriander (Coriandrum sativum L.) cultivars to graded levels of vermicompost", Journal of Spices Aromatic Crops, Vol. 7 No. 2, pp. 141-143.

Van, S. N., Minh, H. D. and Anh, D. N. (2013), "Study on chitosan nanoparticles on biophysical characteristics and growth of robusta coffee in green house", Biocatalysis and Agricultural Biotechnology, Vol. 2 No. 4, pp. 289-294.
Wildy, S. A., Covey, R. P., Lyer, J. C. and Vodit, G. K. (1985), Soil and plant analysis for tree culture, Oxford IBH Publishing Co., New Delhi, India.

Wojdyla, A. T. (2001), "Chitosan in the control of rose disease: six years trials", Bulletin of the Polish Academy of Sciences, Vol. 49, pp. 233-252.

Xie, W., Xu, P. and Liu, Q. (2001), "Antioxidant activity of watersoluble chitosan derivatives", Bioorganic \& Medicinal Chemistry Letters, Vol. 11, pp. 1699-1701.

Zagzog, O. M., Gad, M. M. and Hafez, N. K. (2017), "Effect of Nanochitosan on Vegetative Growth, Fruiting and Resistance of Malformation of Mango", Trends in Horticultural Research, Vol. 7 No. 1, pp. 11-18. 